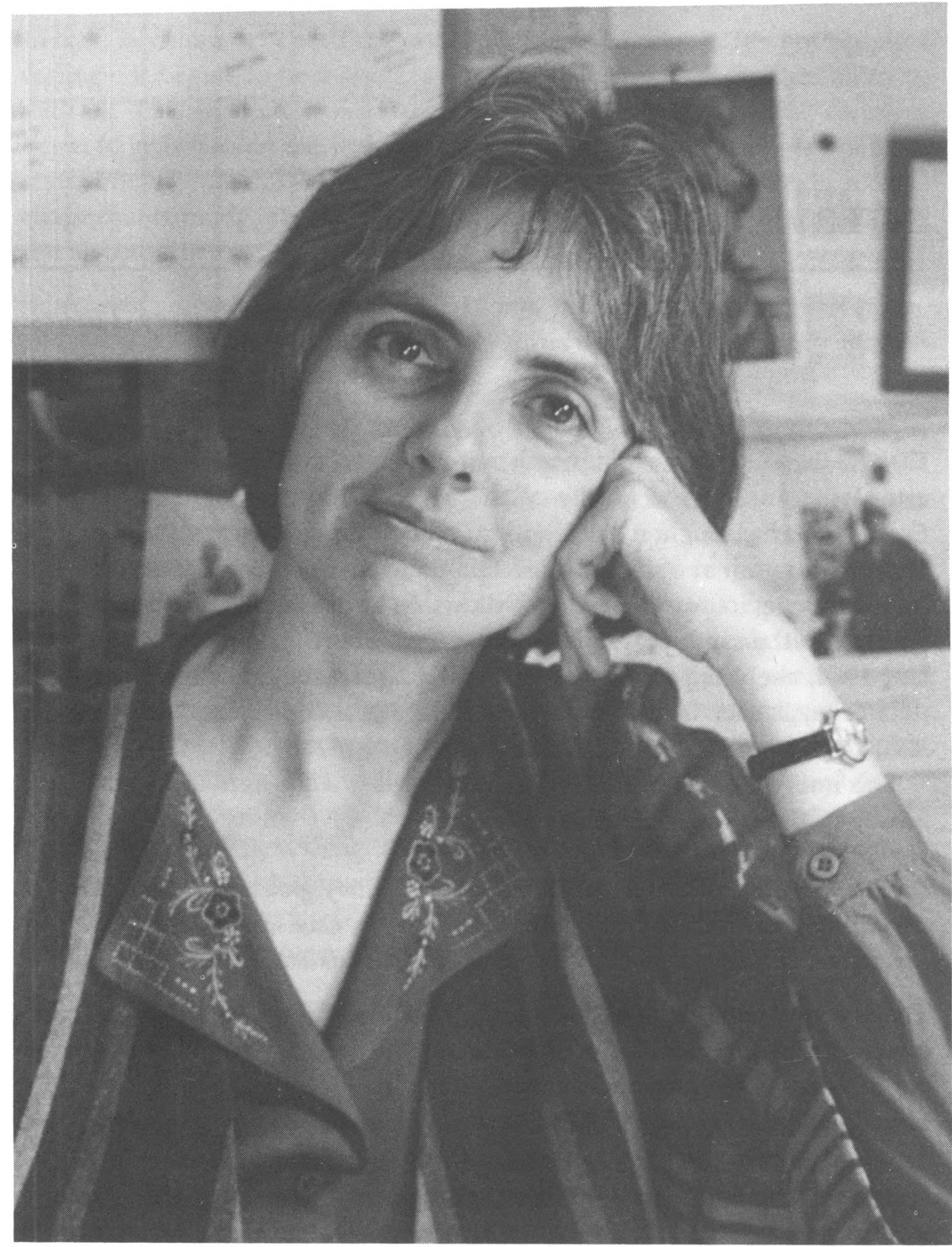

... The boy had positioned among the rosebushes all the pieces of carved stone he'd collected over the years, among them a lamb and a larger than life-sized hand with a ring on the little finger. A stone angel with wide-spread wings knelt, praying, in the center of the rose bed. She was about as high as a man's waist. The old man had threatened many times to crack her in two with an ax handle, believing her to have been taken from one of the spires of the Pope's church in Rome, Italy, which was the seat of the devil.

He watched the angel, waiting for some subtle movement that would betray her-a finger slipped into the wrong position, an eyelid lifted for a glimpse of him, a smile... -Dianne Benedict, "The Stone Angel" 


\section{INTERVIEW WITH DIANNE BENEDICT}

\section{Shirley Tarbell}

DiANNE BENEDICT Is currently Assistant Professor at the University of Southern Maine and on the faculty of the MFA Writing Program at Vermont College. She has taught in the Goddard MFA Writing Program, the Graduate Writing Program at Syracuse University, and the Iowa Writers' Workshop. In 1982, Benedict was awarded a Fellowship at the Breadloaf Writers' Conference. In the same year, she won the Iowa Short Fiction Award. In 1983 and 1984, she was recipient of an Individual Artist's grant from the Ohio Arts Council. Her fiction has appeared in The Atlantic, fiction international, MSS, INTRO, and The Best American Short Stories of 1985.

This interview was conducted in March 1984, while Benedict was on the faculty of the Iowa Writers' Workshop.

One often hears such advice as, "Always let your story grow out of character," or "Always begin with the conflict or the situation." You have said you often start your own stories with an "unpeopled vision." Would you talk about what that means?

That's a very hard thing to talk about. Vision in writing, by its very nature, exists in a realm exclusive of words. And yet one can write a story, made out of words, which embodies that vision. But, you see, the story isn't "talking about" vision. It is very difficult to do so, to speak about vision directly. Yet, certainly, everything I write begins with the element of vision.

It feels to me, inside myself-at the stage that I live in before I actually start to see characters and settings and events - that what I feel within myself is sort of a swelling of the soul. Towards life, particularly towards other people, towards humankind. Sort of a swelling of love, which sounds, as I say it, very sentimental. But it is actually a very vital thing in my life, and in all our lives, to not only feel our connection with each other, but to feel a sort of continuous urgency about our growth, about our evolution, about our problems. And particularly the hour of the world in which we live today draws each one of us very close to humankind over all. And it's that . . that realm ... that some part of me begins to swell towards, to be activated with a sense of urgency towards. And that activation, that coming alive within 
myself, is visionary. That's the only way I can describe it. It's not simply a feeling - it begins to be a seeing, a wisdom of humankind that we all carry with us. This wisdom is visionary. And only after that, as those concerns begin to grow within me with a sense of urgency-sometimes very painful, sometimes so painful I can hardly bear it - that the stories begin to take shape that embody not only the concerns, but the urgency behind them, and the states of being that called them forth. It's hard to explain-very hard.

You've said you write a story by watching it unwind in your mind like a reel of film, and that if you get stuck you simply back up the reel and start again. Do you approach the writing of all your stories this way?

Yes. It strikes me as funny, the way you put that, but it's essentially true. Yes. This is the process for me. This is the actual process of writing for me. For everyone the process of writing is different, and this is my process. I'm an imagist writer, as opposed to a voice writer, though I am getting so I can write more and more out of voice. But in doing so, I'll never leave my imagist roots. The stories, I think, for me will always be pulled along by means of images that keep popping into my mind, always one step ahead, one step ahead, pulling the story along. And yes, as I see the story, as I see the events happen and details of setting, it is like a movie on a screen, happening on a screen. And yes, when I get stuck - Now you see, up to the stuck point, up to that point, the reel was turning, the movie was being played out. It was moving. It was working. And suddenly I come to a stuck point, where I can't picture the next thing. And yes, the way I get by that place is to back up a little bit and go through that nice moving material that was flowing along and working very well. And very often, almost always, the momentum of that will push me beyond the stuck place.

You are now working on a novel. How do you find the writing process differs from the process of writing a story?

Well, everybody has his or her own experience with a novel. My experience with it, I suppose, and the new thing about it for me that wasn't there for me with the stories, first of all is-the major thing, I think, is the number of characters. Although, as I say this, I realize perfectly wonderful novels have been written around only two or three main characters-sometimes only two, and sometimes only one. So it doesn't have to do always with the number of characters. But for me, it seems to.

This I think is more crucial than it seems at the outset, because what happens for me- What's happened for me, in bringing in more characters, is that I have shifted the sphere of focus from the individual life, the development of the individual's psychology or inner life-the growth of the individual-outward to more of a social focus within a group of people. Within this novel I'm writing, I have both. I have the interesting psychological inner life of individual characters, embedded within the life of the group. I have a 
community of people, sort of misfit people, who come together in my novel and end up traveling together on an old bus that they revive and put on the road-it's their home. This community, this little community, is really the first time that I have written with that kind of focus, with the focus on a community or even on a family. I've never even written with a focus on a family. So for me that's a very great difference in writing a novel.

Also the novel is linear. I have a hard time letting go of the central tension of a story, of the central heart's force of a story, that begins to create a curve in the periphery of the story. Stories are linear in the sense that events happen one after the other, and so in a sense create a line. But what happens in a story is-for me-that that line begins to curve, towards closure, and becomes more and more a circle. The curve is created by a tension of something pulling from a center, so that by the time the story is done it's sort of like a mandala. In a story.

What is very hard for me, with the novel, is to let go of that. If you can't let go of that-if you're a story writer who writes that way, and you can't let go of that-what happens to you is that very soon, within ten pages of setting out into the novel, this curve begins to happen; it begins to move you towards closure, so that, by the end of twenty pages certainly, you-everything in you is moving towards closure. And you're curving the piece into a final shape. I find myself doing that again and again, and it's very hard to stop doing that. I've learned now to relax more. I still have this problem, but I'm able to relax more and think in terms of a linear progression that simply moves out. Just moves out and forward, and isn't pulled by the center into a curve or into closure. I think now that my urge, or motivation towards closure, is beginning to be satisfied by chapter closure, by scene closure, or section closure. So I'm more and more able to move forward in the material of this book.

I know that your vision of the world is quite different from Flannery O'Connor's. How do you feel when people compare your work to hers? And why do you believe the comparison is made, given that your philosophies are so different?

Well, it's funny. Recently I was very relieved-in regard to some of the new writing I've been doing, which has a different setting from the stories I wrote in the past-to have had two people come up to me and tell me that my work sounds like the work of Katherine Anne Porter. I found this an enormous relief after nearly five years of being told that I sound like Flannery O'Connor. As to why comparisons are made between my work and that of Flannery O'Connor or Katherine Anne Porter, or between any two writers' work - I think this has to do purely with the element of sound. It doesn't so much - In fact, it seldom has to do with the philosophy, with what you called the philosophy of the writer, the writer's vision, so much as it has to do with the sound of the material. The sound of the stories, the voice of the stories, the way they sound on people's ears. If you sound like another 
writer, you're going to be compared with another writer. And O'Connor and Porter both are southern writers and they write in that voice. And I'm also a southern writer and my characters are southern people, so their language, their dialogue, is in southern vernacular, and of course the narrative language needs to match the characters.

You've said you primarily get at your characters from the outside, through images and dialogue, rather than getting at them as some writers do, from the inside. Would you comment on the point of view from which you see your characters?

Well, yes, that vantage point that I have when I'm creating my characters, when I'm absorbing them, as they're evolving for me, is always on the outside for some reason. I never write in the first person. Writing in the first person immediately gets you into the head of the character, so that you're within the character looking out. And for some reason I find it very difficult to write from that vantage point. I've tried to do it-I've done it as an exercise, periodically. But I always do it very badly.

What do you feel you lose and what do you gain, writing this way?

That's a good question. What do you lose and what do you gain? What you gain is access to a world that begins to move of its own accord before your eyes, that begins to create itself. To unfold before your eyes. It also gives you a way to create characters - that is, from the outside-what they look like, all the little details of their dress, the way they walk, their expressions, their gestures, and what they do. It gives you a way of describing characters that will resonate wonderfully with the reader, because this is the way we always see people in real life. This is the way we experience people in real life. We see them from the outside. We listen to them talk. We watch the expressions on their faces. See, we're never inside another person in real life. So what this does is give you a sort of wonderful immediate creative image that resonates powerfully with the reader. The reader can immediately grasp that character-knows that character. It's a powerful and effective way of giving the character to the reader.

What you lose is-you can't get inside your characters and talk about what they're thinking, talk about what they're feeling, just directly describe thoughts and feelings and opinions. The writing loses a quality of generosity which is a great deal to lose. One of the nicest things about stories and novels written in the first person, or written in a very close third person point of view, where you're inside the heads of characters, you've seen their thoughts, you've been directly given their feelings-what they're feeling-one of the nicest things about that is the sense that the author is being very generous and open to the reader. And that this can be done, that there is no taboo against it. And it creates a sort of relaxed quality that's very, very nice. I wish I could write that way. I'm trying to learn how to do this. Voice writers are much more able to write that way than image writers. 
Where would you say your characters come from? For instance, where did the little boy, Ulysses Montgomery Dade, in the title story of your book Shiny Objects come from?

Well, where my characters come from, I think, is really a matter of process because - Of course, our characters really come from within us. They usually are, or very often are, an aspect of ourselves. Perhaps with some writers this is more true than with others. With me it's very true, I'm sure. But that process is an entirely unconscious one for me, so really to answer the question in a satisfactory way, I can only speak about process-where the characters actually come from in the process of writing. For me, it is a process of choice, questioning, and elimination that I go through as I'm zeroing in, focusing upon, any particular thing in the story. Whether it's a character, or an old sofa, or a road winding through a copse of trees. What I will do-and I'll speak about character particularly-is, I'll begin to ask myself questions, very elementary questions.

Is the character male or female? And the answer will come: Oh, yes, I want it to be a woman. Then the next question will be age. OK. All right. In order to fit best, will this character be an older woman or a young woman, perhaps married with children? Or do I want it to be an old woman? Of course, it has to be an old woman, here in this house. And then the questions continue. All right, is she a large old woman, very sturdy and strong, with a wonderful full head of hair that she keeps up in a bun on the back of her head? Or is she small, and more like a bird, shriveled? So these questions begin to throw pictures up on the screen of my mind, you see, out of which I can begin to select.

And already I'll have a story going. I'll have a sort of a vision, perhaps even a ready-made relationship for that character to fit into. And so, as I ask myself these questions, the answers will always come, about what is going to fit, what is exactly what I want. And I can tell the things that don't fit, the aspects that are wrong for the story. So yes, it's by that process of elimination that I find the characters. That's the process.

It seems that often in your stories, characters suffer from some malady or some defect that sets them apart, separates them from others: the crippled boy Ulysses, in "Shiny Objects"; the deaf man and girl in "Where the Water is Wide"; the dying man in "Unknown Feathers"; even the blind horse. How do these defects function in your stories? What is their significance?

Well, we all have a malady or defect that sets us apart from others in life. Don't you see? And because of this, because we all have it, this is precisely what connects us. This is precisely what relates us to one another, and makes us human to one another. And people spend a great deal of time trying to cover up this fact of their lives. They spend a lot of energy covering up their so-called defects, which they always see as great flaws of being. And the energy expended to do it is terrible. And it always comes as a tremendous 
relief - almost a flood of relief - for a human being who is consistently doing this to reach a place in her life where she discovers that nearly everyone else is doing the same thing, and that in fact the people she thought were so strong and inaccessible to her are actually accessible insofar as she can share her hidden flaws and help them to accept theirs. And the same thing happens in stories-precisely the same thing-that your characters are going to be loved by readers precisely insofar as they help the readers to accept their flaws. Accept them in such a way that they have this flood of relief, of being able to let go of the protective devices or illusions with which they've covered up these things in themselves. That's why flawed characters are so helpful to use and why they're so loved by people. They help us forgive ourselves. And in doing this, we can really begin to live.

In nearly all your stories, animals play an important part-for example, crows in the story "Crows," the blind horse in the story by that name, the little dog the size of a teapot in "Unknown Feathers," the little white-faced cat in "The Stone Angel." What are the reasons for their presence? What is especially significant to you about the human relationship with animals?

Yes, animals are wonderful. Animals are absolutely wonderful. If writers would only understand what they have in terms of material, what they have access to in animals. So few writers will bring animals into their stories, and then when they do, it's often just a dog or just a cat-both of which are very nice to write about. But all animals are very, very powerful. You know, actors say, don't ever bring an animal onto the stage because it'll steal the scene. It's the same thing in a story, although it doesn't steal the scene. It does liven it up tremendously. If writers only understood, this is a device that you can use to create an absolutely wonderful effect with almost no effort. Of course, animals resonate very deeply for us. They take on human qualities - what we think of as human qualities - which are actually qualities we share with animals. And individual animals can be used, and just in themselves they are a picture of certain forces within the human soul.

Of course, we don't write stories about animals-most of us don't. We're writing about human beings. What we're doing is using the animal to show an aspect-an important aspect-of any one of a number of characters. Usually a main character. And very often we use an animal to show what the character is feeling. Animals are full of feeling. They're almost made of feeling. And that's how they're used. They're extremely powerful, and no story is complete without them.

What human feeling would you say the blind horse illustrates?

Yes, that's a good example. You see, in that story, the characters themselves are quite lost. They're trying in their lives to go forward. They're trying to search out their direction, their future, answers to their problems. And they feel like they're moving through a sort of white cloud, through which they 
can't see. They feel very lost. And in fact they feel blind. What they feel like is happening to them is that they're constantly bumping into things. They're constantly having something come at them without warning and knock them down. So to get into the story with an animal-particularly a horseA horse is a creature that moves very quickly and effectively through space. A horse runs at great speed. This is how we think of a horse. So when you have a horse that's blind and can't run, and can only stumble into the yard and bump into the pump, and run painfully and suddenly up against a fence, and be knocked down and threatened by cars-you have a very effective picture of characters who are lost and stumbling in trying to live their lives.

Would you comment on the humor in your stories? Often there's humor mixed with sadness. Some of the dialogue between Ulysses and Mrs. Gilnetter in "Shiny Objects" is very funny, for example. Even the little teapot-shaped dog in "Unknown Feathers" has his humorous moments. There's a substantial level of humor in the relationship between the grandfather and the little girl in "Looking for Rain." From what place does such humor arise, do you think? How does it function in your stories?

I think I can answer that very simply. I always let the characters in my stories find their own humor. I let the humor evolve out of them in a natural way. I never bring it to them. I never try to say something funny-certainly never directly. I will never try to say something funny about anything. Whatever humor is in my stories always comes from the characters themselves, in a natural way. I don't plan it or just "decide" to weave it in. 